\title{
Risk Factors for Cerebral Palsy in Brazilian Children: A Case-Control Study
}

\author{
Fatores de risco para paralisia cerebral em crianças brasileiras: Um estudo de caso-controle \\ Factores de riesgo de parálisis cerebral en niños brasileños: Un estudio de casos y controles
}

Received: 04/14/2021 | Reviewed: 04/21/2021 | Accept: 04/24/2021 | Published: 05/09/2021

\author{
Marcus Valerius da Silva Peixoto \\ ORCID: https://orcid.org/0000-0001-9047-5875 \\ Federal University of Sergipe, Brazil \\ E-mail: peixotovalerius@gmail.com \\ Andrezza Marques Duque \\ ORCID: https://orcid.org/0000-0002-8775-1565 \\ Federal University of Sergipe, Brazil \\ E-mail: andrezza.duque@yahoo.com.br \\ Allan Dantas dos Santos \\ ORCID: https://orcid.org/0000-0002-6529-1887 \\ Federal University of Sergipe, Brazil \\ E-mail: allanufs@hotmail.com \\ Shirley Verônica Melo Almeida Lima \\ ORCID: https://orcid.org/0000-0002-9062-0742 \\ Federal University of Sergipe, Brazil \\ E-mail: shirleymelo.lima@gmail.com \\ Caíque Jordan Nunes Ribeiro \\ ORCID: https://orcid.org/0000-0001-9767-3938 \\ Federal University of Sergipe, Brazil \\ E-mail: caiquejordan_enf@yahoo.com.br \\ Silvia Maria Voci \\ ORCID: https://orcid.org/0000-0002-7087-7233 \\ Federal University of Sergipe, Brazil \\ E-mail: smvoci@uol.com.br \\ Susana de Carvalho \\ ORCID: https://orcid.org/0000-0001-8708-3205 \\ Federal University of Sergipe, Brazil \\ E-mail: susana_carvalho@uol.com.br \\ Marco Antônio Prado Nunes \\ ORCID: https://orcid.org/0000-0002-5416-4954 \\ Federal University of Sergipe, Brazil \\ E-mail: nunes.ma@outlook.com
}

\begin{abstract}
Background: Cerebral palsy is the main cause of physical disability in childhood. Objectives: This study analyzed prenatal and perinatal risk factors that contribute to cerebral palsy in Brazilian children. Methods: A case-control study was conducted with 2- to 10-year-old children in the city of Aracaju, Sergipe, Brazil. The cases were population-based, selected from the Primary Health Care services. The controls were selected from the database of the Brazilian Live Births Information System. Controls were paired with cases by gender, year, and hospital of birth. Results: A total of 570 participants (114 cases and 456 controls) were studied. Most of the participants were male, with bilateral spastic cerebral palsy. Among the prenatal factors examined, the presence of congenital anomalies was significantly different between cases and controls $(\mathrm{OR}=54.28,[95 \% \mathrm{CI} 12.55,234.86])$. The analysis of perinatal factors revealed significant differences between cases and controls in low birth weight $(\mathrm{OR}=3.8,[95 \% \mathrm{CI} 2.34,6.16])$, preterm birth $(\mathrm{OR}=2.31$, [95\% CI 1.41, 3.80]), and low Apgar scores (OR $=14.73$, [95\% CI 5.27, 41.15]). Conclusions: The main prenatal and perinatal factors associated with cerebral palsy in our population were congenital anomalies, low Apgar scores, low birth weight, and preterm birth. The perinatal period had more risk factors, demanding a deeper study of their causes and of possible preventive measures.
\end{abstract}

Keywords: Cerebral palsy; Epidemiology; Risk factors; Case-control studies; Disabled children.

\section{Resumo}

Introdução: A paralisia cerebral é a principal causa de deficiência física na infância. Objetivos: Este estudo analisou os fatores de risco pré-natal e perinatal que contribuem para a paralisia cerebral em crianças brasileiras. Métodos: Foi realizado um estudo caso-controle com crianças de 2 a 10 anos de idade na cidade de Aracaju, Sergipe, Brasil. Os casos eram de base populacional, selecionados nos serviços de Atenção Básica à Saúde. Os controles foram selecionados no banco de dados do Sistema de Informações sobre Nascidos Vivos do Brasil. Os controles foram pareados com os casos 
por sexo, ano e hospital de nascimento. Resultados: Um total de 570 participantes (114 casos e 456 controles) foram estudados. A maioria dos participantes era do sexo masculino, com paralisia cerebral espástica bilateral. Entre os fatores pré-natais examinados, a presença de anomalias congênitas foi significativamente diferente entre casos e controles (OR $=54,28$, [IC 95\% 12,55, 234,86]). A análise dos fatores perinatais revelou diferenças significativas entre casos e controles em baixo peso ao nascer ( $\mathrm{OR}=3,8$, [IC 95\% 2,34, 6,16]), parto prematuro (OR = 2,31, [IC 95\% 1,41, 3,80]) e baixo Pontuações de Ápgar (OR = 14,73, [IC 95\% 5,27, 41,15]). Conclusões: Os principais fatores pré-natais e perinatais associados à paralisia cerebral em nossa população foram anomalias congênitas, baixo índice de Ápgar, baixo peso ao nascer e prematuridade. O período perinatal apresentou mais fatores de risco, exigindo um estudo mais aprofundado de suas causas e de possíveis medidas preventivas.

Palavras-chave: Paralisia cerebral; Epidemiologia; Fatores de risco; Estudos de casos e controles; Crianças com deficiência.

\section{Resumen}

Antecedentes: la parálisis cerebral es la principal causa de discapacidad física en la infancia. Objetivos: Este estudio analizó los factores de riesgo prenatales y perinatales que contribuyen a la parálisis cerebral en niños brasileños. Métodos: se realizó un estudio de casos y controles con niños de 2 a 10 años de la ciudad de Aracaju, Sergipe, Brasil. Los casos fueron poblacionales, seleccionados de los servicios de Atención Primaria de Salud. Los controles fueron seleccionados de la base de datos del Sistema Brasileño de Información de Nacidos Vivos. Los controles se emparejaron con casos por sexo, año y hospital de nacimiento. Resultados: Se estudiaron un total de 570 participantes (114 casos y 456 controles). La mayoría de los participantes eran hombres, con parálisis cerebral espástica bilateral. Entre los factores prenatales examinados, la presencia de anomalías congénitas fue significativamente diferente entre casos y controles $(\mathrm{OR}=54,28$, [IC 95\% 12,55, 234,86]). El análisis de factores perinatales reveló diferencias significativas entre casos y controles en bajo peso al nacer $(\mathrm{OR}=3,8,[\mathrm{IC} 95 \%$ 2,34, 6,16]), parto prematuro (OR = 2,31, [IC 95\% 1,41, 3,80]) y bajo Puntuaciones de Apgar (OR = 14,73; [IC del 95\%: 5,27; 41,15]). Conclusiones: Los principales factores prenatales y perinatales asociados a la parálisis cerebral en nuestra población fueron las anomalías congénitas, el Apgar bajo, el bajo peso al nacer y el parto prematuro. El período perinatal presentó más factores de riesgo, exigiendo un estudio más profundo de sus causas y de posibles medidas preventivas.

Palabras clave: Parálisis cerebral; Epidemiología; Factores de riesgo; Estudios de casos y controles; Niños con discapacidad.

\section{Introduction}

Cerebral palsy (CP) is the leading cause of childhood physical disability. It encompasses a group of permanent movement and postural deficiencies that impair activity and are caused by non-progressive injuries that occur in the development of the fetal or infant brain. Motor impairment from CP may also be accompanied by primary or secondary disturbances of sensation, perception, cognition, communication, and behavior, by epilepsy, and by secondary musculoskeletal problems (Graham et al., 2016; Rosenbaum et al., 2007).

The known risk factors for $\mathrm{CP}$ in full-term children in developed countries are placental abnormalities, congenital malformations, low birth weight, meconium aspiration syndrome, emergency cesarean delivery, asphyxia during delivery, neonatal seizures, respiratory distress syndrome, hypoglycemia, and neonatal infections (MCINTYRE et al., 2013; Pakula, Van Naarden Braun, \& Yeargin-Allsopp, 2009).

Small for gestational age (SGA) and low birth weight may be considered as the main risk factors for CP (Colver, Fairhurst, \& Pharoah, 2014; Graham et al., 2016). In addition to the multifactorial clinical aspects, the causes of CP can also be related to healthcare management and quality (Saadi, Sutan, Dhaher, \& Alshaham, 2012).

A systematic review reported a prevalence of 2.11 per 1,000 live births (Oskoui, Coutinho, Dykeman, Jetté, \& Pringsheim, 2013). The low prevalence of CP makes it difficult to identify risk factors. However, case-control studies provide a methodological tool that can contribute to their understanding (Walstab et al., 2002).

Most of the epidemiological studies on CP were conducted in developed countries (Kate Himmelmann, Ahlin, Jacobsson, Cans, \& Thorsen, 2011; Mcintyre et al., 2013; Oskoui et al., 2013; Sellier et al., 2016), despite efforts by researchers from various developing countries (Daher \& El-khairy, 2013; Donald et al., 2014; Gao et al., 2017; Oztürk et al., 2007; Petridou et al., 1996; Saadi et al., 2012; Serdaroğlu, Cansu, Özkan, \& Tezcan, 2006). An increased risk of CP in low- and middle-income 
countries, due to exposure to perinatal events, has been suggested (Gladstone, 2010; Graham et al., 2016). The epidemiological aspects of $\mathrm{CP}$ need further clarification, especially in socioeconomic contexts characterized by social inequities. Therefore, this study aimed to analyze prenatal and perinatal risk factors contributing to $\mathrm{CP}$ in Brazilian children.

\section{Methodology}

\section{Study Design}

A case-control study was conducted in the city of Aracaju, Sergipe, Brazil. The case-control study is a type of retrospective epidemiological clinical study, which is indicated to investigate uncommon or rare diseases, such as CP. First, the researchers identify one group of subjects with the disease and another without it. Subsequently, it is necessary to look backward to explore differences in predictor variables that may explain why the cases got the disease and the controls did not (Hulley, Cummings, Browner, Grady \& Newman, 2013). Thus, our study was organized in two stages: a) Identification of CP cases in a population-based survey of the whole city; b) Search of prenatal and birth information on cases and controls in the records of the Brazilian Ministry of Health Live Births Information System (SINASC).

\section{Study area}

According to the Brazilian Institute of Geography and Statistics (IBGE), Aracaju has a surface of $181.90 \mathrm{~km}^{2}$, an estimated population of 623,766 , and no rural areas. The city provides primary health care coverage for $93 \%$ of the population, with 44 health units and 144 primary health care teams, each team including medical, nursing, and community health professionals. Hospital care for pregnant women is provided by two maternity hospitals.

\section{Data Collection}

The cases were identified in the early stages of the research, through an active search in the 44 primary health care units of the city. Primary care teams collaborated as key informants, based on their knowledge of their respective geographical sectors. After the identification of the cases, a questionnaire was administered to the biological mothers of children with $\mathrm{CP}$, at their homes. Gestational history and childbirth information were gathered from the SINASC in the second stage of the research.

Inclusion criteria: Children 0-2 years old, born between 2006 and 2016, living in Aracaju, with a diagnosis of cerebral palsy according to the International Classification of Diseases - ICD-10 (G.80.0-9) (World Health Organization, 2016). Exclusion Criteria: Children with post-natal cerebral palsy, those with absent biological mothers, and those diagnosed with progressive encephalopathies.

The controls were selected at the SINASC. The cases were excluded from the database for the selection of the controls, which were automatically drawn by means of a script with the R software. The pairing was performed by gender, hospital and year of birth at the rate of $1: 4$.

\section{Variables}

The Brazilian Ministry of Health Live Birth Information System collects data on 106 variables. The final analysis included 14 variables, organized as follows: Maternal age (adolescent mother: $\leq 19$ years old; adult mother: 20-34 years old; mother age 35 and above); maternal schooling ( $\leq 3$ years of schooling, $4-7$ years of schooling, $8-11$ years of schooling, $\geq 12$ years of schooling); mother's marital status; number of children alive; historic of number of fetal losses and miscarriages, gestational age (preterm: $\leq 36$ weeks; full-term: 37-42 weeks); single or multiple pregnancy; type of delivery (natural or Csection); number of prenatal consultations; child's gender; Apgar 1' (normal: $\geq 7$; low: $\leq 6$ ); Apgar 5' (normal: $\geq 7$; low: $\leq 6$ ); weight at birth (normal: $\geq 2500 \mathrm{~g}$; low: $<2500 \mathrm{~g}$ ); and presence or absence of congenital anomalies. 


\section{Data Analysis}

Descriptive analysis of absolute and relative frequencies of categorical variables and measurements of central tendency and variability for numerical variables were performed. Differences between proportions were analyzed using Pearson's chisquared test or Fisher's exact test, while Student's t-test was used to compare two independent samples of numerical variables. Univariate and multivariate logistic regression was applied to identify predictive factors.

\section{Ethical Aspects}

The research was approved by the Federal University of Sergipe's Research Ethics Committee (opinion number "1.177.455") which abides by the ethical principles of the Brazilian National Council of Ethics in Research (Conselho Nacional de Ética em Pesquisa do Brasil - CONEP) and the Declaration of Helsinki.

\section{Results}

The study included 570 participants (114 cases and 456 controls). Most of the participants of cases group were male $53.51 \%$ (61), with type of cerebral palsy bilateral spastic 40.35\% (46), followed by unilateral spastic types, $19.29 \%$ (22) dyskinetic $1.75 \%$ (2), ataxic $2.63 \%$ (3) and $35.96 \%$ (41) uninformed.

When analyzing the mothers' socio-demographic characteristics by univariate logistic regression, a significantly higher rate of $\mathrm{CP}$ was found in the advanced age group ( $\mathrm{OR}=3.25$ [95\% CI 1.88, 5.63]). The stratum of mothers in adulthood was found to be protective ( $\mathrm{OR}=0.58$, [95\% CI 0.38, 0.89]). No differences were observed for marital status. Mothers with higher schooling were more likely to have children with $\mathrm{CP}(\mathrm{OR}=1.66$, [95\% CI 1.00, 2.75]) (Table 1).

Table 1 - Absolute and relative frequencies and odds ratio for cerebral palsy according to the sociodemographic characteristics of mothers.

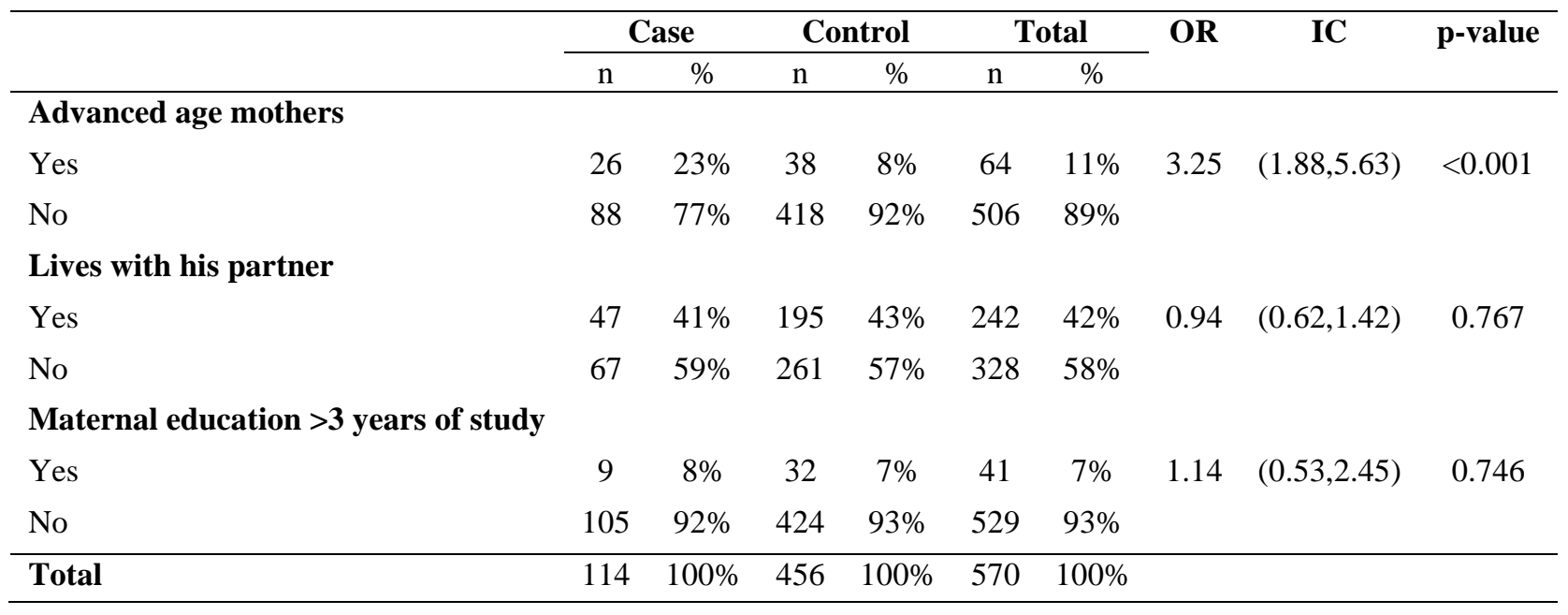

OR: Odds Ratio; CI: Confidence Interval. Source: Own authorship.

Among the prenatal aspects investigated, the presence of congenital anomalies showed a significant effect, with the highest probability of $\mathrm{CP}$ occurrence in the univariate analysis ( $\mathrm{OR}=54.28$, [95\% CI 12.55, 234.86]). The number of prenatal consultations and the history of other pregnancies did not correlate with differences in CP occurrence. The analysis of the perinatal factors revealed significant differences for low birth weight, gestational age of less than 37 weeks and Apgar lower than 7 at one and five minutes. Multiple gestations, type of delivery and time of birth were not significantly associated with $\mathrm{CP}$ occurrence (Table 2). 
Table 2 - Absolute and relative frequencies and odds ratio for cerebral palsy according to prenatal and parinatal characteristics.

\begin{tabular}{|c|c|c|c|c|c|c|c|c|c|}
\hline & \multicolumn{2}{|c|}{ Case } & \multicolumn{2}{|c|}{ Control } & \multicolumn{2}{|c|}{ Total } & \multirow[t]{2}{*}{ OR } & \multirow[t]{2}{*}{ IC } & \multirow[t]{2}{*}{ p-value } \\
\hline & $\mathrm{n}$ & $\%$ & $\mathrm{n}$ & $\%$ & $\mathrm{n}$ & $\%$ & & & \\
\hline \multicolumn{10}{|c|}{ Prenatal consultations } \\
\hline$<$ de 6 consultations & 62 & $54 \%$ & 220 & $48 \%$ & 282 & $49 \%$ & 1.28 & $(0.85,1.93)$ & 0.241 \\
\hline$\geq$ de 7 consultations & 52 & $46 \%$ & 236 & $52 \%$ & 288 & $51 \%$ & & & \\
\hline \multicolumn{10}{|c|}{ Adequate prenatal care* } \\
\hline Yes & 70 & $61 \%$ & 264 & $58 \%$ & 334 & $59 \%$ & 1.15 & $(0.76,1.75)$ & 0.512 \\
\hline No & 44 & $39 \%$ & 191 & $42 \%$ & 235 & $41 \%$ & & & \\
\hline \multicolumn{10}{|l|}{ History of live fetus } \\
\hline Yes & 54 & $47 \%$ & 218 & $48 \%$ & 272 & $48 \%$ & 0.98 & $(0.65,1.48)$ & 0.933 \\
\hline No & 60 & $53 \%$ & 238 & $52 \%$ & 298 & $52 \%$ & & & \\
\hline \multicolumn{10}{|c|}{ History of a dead fetus } \\
\hline Yes & 18 & $16 \%$ & 84 & $18 \%$ & 102 & $18 \%$ & 0.83 & $(0.48,1.45)$ & 0.512 \\
\hline No & 96 & $84 \%$ & 372 & $82 \%$ & 468 & $82 \%$ & & & \\
\hline \multicolumn{10}{|l|}{ Anomalies } \\
\hline Yes & 22 & $19 \%$ & 2 & $0.4 \%$ & 24 & $4 \%$ & 54.28 & $(12.55,234.86)$ & $<0.001$ \\
\hline No & 92 & $81 \%$ & 454 & $99.6 \%$ & 546 & $96 \%$ & & & \\
\hline \multicolumn{10}{|l|}{ Type of pregnancy } \\
\hline Multiple & 3 & $3 \%$ & 16 & $4 \%$ & 19 & $3 \%$ & 0.74 & $(0.21,2.60)$ & 0.641 \\
\hline Single & 111 & $97 \%$ & 440 & $96 \%$ & 551 & $97 \%$ & & & \\
\hline \multicolumn{10}{|l|}{ Type of Delivery } \\
\hline Caesarean & 55 & $48 \%$ & 212 & $46 \%$ & 267 & $47 \%$ & 1.07 & $(0.71,1.62)$ & 0.737 \\
\hline Vaginal & 59 & $52 \%$ & 244 & $54 \%$ & 303 & $53 \%$ & & & \\
\hline \multicolumn{10}{|l|}{ Birth time } \\
\hline Nigth & 53 & $46 \%$ & 197 & $43 \%$ & 250 & $44 \%$ & 1.14 & $(0.76,1.72)$ & 0.527 \\
\hline Day & 61 & $54 \%$ & 259 & $57 \%$ & 320 & $56 \%$ & & & \\
\hline \multicolumn{10}{|l|}{ Low weight } \\
\hline Yes & 38 & $33 \%$ & 53 & $12 \%$ & 91 & $16 \%$ & 3.80 & $(2.34,6.16)$ & $<0.001$ \\
\hline No & 76 & $67 \%$ & 403 & $88 \%$ & 479 & $84 \%$ & & & \\
\hline \multicolumn{10}{|l|}{ Preterm } \\
\hline Yes & 30 & $26 \%$ & 61 & $13 \%$ & 91 & $16 \%$ & 2.31 & $(1.41,3.80)$ & $<0.001$ \\
\hline No & 84 & $74 \%$ & 395 & $87 \%$ & 479 & $84 \%$ & & & \\
\hline \multicolumn{10}{|l|}{ Abnormal apgar 1' } \\
\hline Yes & 32 & $28 \%$ & 38 & $8 \%$ & 70 & $12 \%$ & 4.29 & $(2.54,7.27)$ & $<0.001$ \\
\hline No & 82 & $72 \%$ & 418 & $92 \%$ & 500 & $88 \%$ & & & \\
\hline \multicolumn{10}{|l|}{ Abnormal apgar 5, } \\
\hline Yes & 16 & $14 \%$ & 5 & $1 \%$ & 21 & $4 \%$ & 14.73 & $(5.27,41.15)$ & $<0.001$ \\
\hline No & 98 & $86 \%$ & 451 & $99 \%$ & 549 & $96 \%$ & & & \\
\hline Total & 114 & $110 \%$ & 456 & $100 \%$ & 570 & $100 \%$ & & & \\
\hline
\end{tabular}

* Adequate prenatal refers to the number of consultations proportional to gestational age. OR: Odds Ratio; CI: Confidence Interval. Source: Own authorship.

Multivariate logistic regression showed a significant association with birth weight, 5-minute Apgar score, maternal age and congenital anomalies $(\mathrm{p}<0.05)$ (Table 3). 
Table 3 - Logistic regression model of risk factors for cerebral palsy.

\begin{tabular}{lcccc}
\hline & Coefficient & Standard Error & $\mathbf{z}$ & p-value \\
\hline Weigth & -0.001 & 0.001 & -3.777 & $<0.001$ \\
Apgar 1' & -0.132 & 0.111 & -1.188 & 0.235 \\
Apgar abnormal 5, & -0.343 & 0.164 & -2.087 & 0.037 \\
Maternal age & 0.073 & 0.020 & 3.657 & $<0.001$ \\
Cesarian delivery & -0.128 & 0.258 & -0.498 & 0.619 \\
Mothers with less than 3 years of study & -0.065 & 0.477 & -0.137 & 0.891 \\
No prenatal consultation & -0.040 & 0.266 & -0.152 & 0.879 \\
Pre-term & -0.442 & 0.417 & -1.060 & 0.289 \\
Multiple pregnancy & -0.427 & 0.686 & -0.623 & 0.533 \\
History dead fetus & -0.537 & 0.346 & -1.553 & 0.120 \\
Congenital anomaliy & 4.219 & 0.764 & 5.525 & $<0.001$ \\
Mothers living with partner & -0.130 & 0.266 & -0.489 & 0.625 \\
\hline
\end{tabular}

Source: Own authorship.

\section{Discussion}

$\mathrm{CP}$ is a condition that causes several impairments throughout lifespan of children and their families. Then, the patients need a qualified follow-up that encompasses interventions of multiple domains (e. g. motor, occupational and neuropsychopedagogical) (Coelho \& Soares, 2020; Oliveira et al., 2021; Silva, Barata, Silva, \& Marcelino, 2020).

Congenital anomalies had the largest effect in both the univariate and multivariate analyses. Congenital alterations in the development of the CNS of the fetus may determine CP either by themselves, or by increasing the probability of problems occurring during labor, including asphyxia (Gurbuz, Karateke, Yilmaz, \& Kabaca, 2006; Nelson \& Blair, 2015).

Microcephaly is the most common congenital defect in cerebral palsy, followed by other changes such as hydrocephalus and anomalies of the corpus callosum (Nelson \& Blair, 2015). A study in Norway showed a high proportion of congenital anomalies $(25 \%)$ among children with late-onset or preterm CP. This type of alteration was associated with a 90 -fold increase in risk (Jystad et al., 2017).

Further studies are needed to analyze the causes of the congenital anomalies that are causing CP in our population: Although some such anomalies have genetic causes, Brazil still faces an epidemic of persistent and preventable transmissible infections, such as syphilis and Zika virus, that can lead to congenital anomalies (Marcondes \& Ximenes, 2015; Victora et al., 2011). Anomalies caused by consanguinity, use of alcohol, tobacco, or other drugs, and unsafe abortion attempts should also be considered.

A low Apgar scores at one and five minutes stood out as an important factor predicting $\mathrm{CP}$, with alterations at five minutes leading to a 14.73 times greater chance of CP. This result was confirmed by the significance of this factor also in multivariate analysis. Other studies found similar results (Gurbuz et al., 2006; Jacobsson et al., 2002; O'Callaghan et al., 2011; Stelmach, Pisarev, \& Talvik, 2005) one of them reporting a 13.2-fold higher risk of CP for low Apgar scores (Gurbuz et al., 2006). The authors report that an Apgar score less than 7 at one or five minutes increased the probability of occurrence of CP, especially in preterm infants.

Low Apgar scores should not be considered the cause of CP, because the score is a composite of clinical signs, and a reflection of neonatal cardiorespiratory function that may reflect an acute or chronic fetal impairment. However, these scores are used as indirect manifestations of asphyxia at birth (Gurbuz et al., 2006; Lie, Grøholt, \& Eskild, 2010; O'Callaghan et al., 2011). Although low Apgar scores can have other possible causes, researchers believe that they could be considered a marker of causal 
factors underlying cerebral palsy and related deficiencies (Lie et al., 2010; Persson, Razaz, Tedroff, Joseph, \& Cnattingius, 2018).

Some evidence has been produced indicating that asphyxia at birth may not be the main cause of $\mathrm{CP}$, and that prenatal factors have a larger role in both preterm and full-term children (Nelson \& Blair, 2015) However, neonatal asphyxia is an event of great prevalence in Brazil. A study revealed that $41 \%$ of fetal deaths are caused by intrapartum asphyxia, even in hospital deliveries (Victora et al., 2011).

Our results indicate that intrapartum events, such as asphyxiation, can play a significant role, second only to that of congenital anomalies, in increasing the probability of CP.

There is a 3.8 times greater chance of CP in infants below $2500 \mathrm{~g}$, and the association remains significant even after multivariate analysis adjustments. These findings are reiterated in the international literature, which considers low birth weight as one of the main risk factors. Several authors found a weight below $2500 \mathrm{~g}$ to be a perinatal risk factor (Gurbuz et al., 2006; Lie et al., 2010; Yeargin-Allsopp et al., 2008).

Preterm birth also increased the probability of CP in our population. Similar data were found in other studies, that found a strong association with this risk factor (Gao et al., 2017; Gurbuz et al., 2006; Hirvonen et al., 2014; Jacobsson et al., 2002; Moster, Wilcox, Vollset, Markestad, \& Lie, 2010; O’Callaghan et al., 2011; Stelmach et al., 2005). However, it is important to note that CP can affect a large proportion of full-term babies, since a Swiss study revealed that $60 \%$ of all children with CP were born at the appropriate gestational age (Ahlin et al., 2013; K. Himmelmann \& Uvebrant, 2018). In a survey conducted in China, gestational age between 37 and 41 weeks at birth was found to be protective against CP (Gao et al., 2017).

Improvements in health care in the last decades led to increased survival of preterm infants, which however may coexist with permanent neurological sequelae. We emphasize the importance of better investigating the causes of preterm births in the Brazilian context, to improve prenatal and neonatal care to avoid neurological injuries and deficiencies.

Since the year 2000, the prevalence of low birth weight in Brazil has remained stable at the level of $8 \%$, notwithstanding the growth in the number of preterm births. According to a survey, the majority of preterm newborns in Brazil have gestational age between 34 and 36 weeks, and weigh more than 2500 grams (Victora et al., 2011).

We propose the hypothesis that in the study population, low-weight and preterm infants are more exposed to events that cause CP-inducing damage, including anoxia. It would be important to conduct further studies to verify the association of these causes with CP in Brazil.

Among the socio-demographic aspects, advanced maternal age was associated with CP. Another study that found similar results argues that older women are highly vulnerable to obesity, gestational diabetes, gestational hypertension, and other conditions that increase the risk of preterm birth, low birth weight, fetal distress, SGA, and other abnormal perinatal outcomes (Gao et al., 2017). The cohabitation of the mother and her companion did not show any association with CP in our population, but another study in Sweden found it to be a risk factor (Ahlin et al., 2013).

One of the prerogatives of the Brazilian health system is universal access to prenatal health monitoring in primary care, and to diagnostic and therapeutic support services. The lack of significant association between prenatal follow-up and CP must be carefully interpreted, and possibly further investigated in future studies. We can formulate two hypotheses in this regard: (1) Prenatal quality analysis would be a better indicator, since the coverage is practically universal, and the number of consultations does not necessarily reflect the health status of women. (2) Unwanted outcomes are due to childbirth itself.

A literature review shows that despite high prenatal coverage in Brazil, this type of health care is poorly integrated into hospital care. The author cites data from a survey conducted in the metropolitan region of Rio de Janeiro, showing that one out of three women in labor had to seek more than one maternity hospital to be hospitalized (Victora et al., 2011).

Vaginal or cesarean delivery, and delivery during the day or night shift, did not show a significant association with CP. 
Data from another case-control study show similar results (Gurbuz et al., 2006). The increase in the rate of cesareans in the last decades did not decrease CP rates (Nelson \& Blair, 2015). Therefore, the increase in surgical interventions cannot be justified by the need to decrease the risk of $\mathrm{CP}$.

This study had some limitations worth highlighting, even though they did not compromise the research design. Some variables related to the prenatal and perinatal periods, that are known risk factors according to the literature, were not used since they are not present in the SINASC records. For instance, it was not possible to access data on maternal infectious or chronic diseases, use of prenatal and perinatal drugs, consanguinity, or harmful habits such as smoking, alcoholism and the use of other drugs. Many events that result in CP may also relate to these variables: Therefore, we encourage further research to be conducted in Brazil following this perspective, including differentiating how risk factors determine different types of CP.

The main advantage of this study consisted in its population-based design, which guarantees greater consistency of the results. The cases were gathered from all over the city, avoiding possible selection biases. Increasing our knowledge about gestation, delivery, and birth of children with $\mathrm{CP}$ can improve our response capacity and reduce the causes of $\mathrm{CP}$ and the damage it inflicts.

\section{Conclusion}

In conclusion, the main prenatal and perinatal factors associated with cerebral palsy in our population were congenital anomalies, low Apgar scores, low birth weight, reduced gestational age, and advanced mother age. The perinatal period was associated to more risk factors, demanding a deeper study of causes and preventive measures. The results of this study add to the existing knowledge on the risk factors for cerebral palsy in Brazil and can serve as the basis for comparisons with data from other countries.

Future research with longitudinal follow-up since the prenatal period, including other associated factors, may explain better the occurrence of $\mathrm{CP}$ in Brazil.

\section{References}

Ahlin, K., Himmelmann, K., Hagberg, G., Kacerovsky, M., Cobo, T., Wennerholm, U. B., \& Jacobsson, B. (2013). Non-infectious risk factors for different types of cerebral palsy in term-born babies: A population-based, case-control study. BJOG: An International Journal of Obstetrics and Gynaecology, 120(6), 724731. https://doi.org/10.1111/1471-0528.12164

Coelho, C. P., \& Soares, R. G. (2020). Estudo de caso com intervenções Neuropsicopedagógicas: estímulos à possibilidades cognitivas. Research, Society and Development, 9(4), e173943065. 10.33448/rsd-v9i4.3065

Colver, A., Fairhurst, C., \& Pharoah, P. O. D. (2014). Cerebral palsy. The Lancet, 383(9924), 1240-1249. https://doi.org/10.1016/S0140-6736(13)61835-8

Daher, S., \& El-khairy, L. (2013). Risk factors for cerebral palsy in Palestinian children: a case-control study. The Lancet, 382, S8. 10.1016/S01406736(13)62580-5

Donald, K. A., Neuro, M. P., Samia, P., Neuro, M. P., Kakooza-mwesige, A., \& Bearden, D. (2014). Pediatric Cerebral Palsy in Africa: A Systematic Review. Seminars in Pediatric Neurology, 21(1), 30-35. 10.1016/j.spen.2014.01.001

Gao, J., Zhao, B., He, L., Sun, M., Yu, X., \& Wang, L. (2017). Risk of cerebral palsy in Chinese children: A N:M matched case control study. Journal of Paediatrics and Child Health, 53(5), 464-469. 10.1111/jpc.13479

Gladstone, M. (2010). A review of the incidence and prevalence, types and aetiology of childhood cerebral palsy in resource-poor settings. Annals of Tropical Paediatrics, 30(3), 181-196. 10.1179/146532810X12786388978481

Graham, H. K., Rosenbaum, P., Paneth, N., Dan, B., Lin, J.-P., Damiano, D. L., \& Lieber, R. L. (2016). Cerebral palsy. Nature Reviews Disease Primers, 2(1), 15082. 10.1038/nrdp.2015.82

Gurbuz, A., Karateke, A., Yilmaz, U., \& Kabaca, C. (2006). The role of perinatal and intrapartum risk factors in the etiology of cerebral palsy in term deliveries in a Turkish population. Journal of Maternal-Fetal and Neonatal Medicine, 19(3), 147-155. 10.1080/14767050500476212

Himmelmann, K., \& Uvebrant, P. (2018). The panorama of cerebral palsy in Sweden part XII shows that patterns changed in the birth years 2007-2010. Acta Paediatrica, International Journal of Paediatrics, 107(3), 462-468. 10.1111/apa.14147 
Himmelmann, K., Ahlin, K., Jacobsson, B., Cans, C., \& Thorsen, P. (2011). Risk factors for cerebral palsy in children born at term. Acta Obstetricia et Gynecologica Scandinavica, 90(10), 1070-1081. 10.1111/j.1600-0412.2011.01217.x

Hirvonen, M., Ojala, R., Korhonen, P., Haataja, P., Eriksson, K., Gissler, M., \& Tammela, O. (2014). Cerebral Palsy Among Children Born Moderately and Late Preterm. Pediatrics, 134(6), e1584-e1593. 10.1542/peds.2014-0945

Huley, S. B., Cummings, S. R., Browner, W. S., Grady, D. G., \& Newman, T. B. (2013). Designing clinical research. Philadelphia, USA: Lippincott Williams $\&$ Wilkins.

Jacobsson, B., Hagberg, G., Hagberg, B., Ladfors, L., Niklasson, A., \& Hagberg, H. (2002). Cerebral palsy in preterm infants: a population-based case-control study of antenatal and intrapartal risk factors. Acta Paediatrica, 91(8), 946-951. https://doi.org/10.1080/080352502760148685

Jystad, K. P., Strand, K. M., Bjellmo, S., Lydersen, S., Klungsöyr, K., Stoknes, M., \& Vik, T. (2017). Congenital anomalies and the severity of impairments for cerebral palsy. Developmental Medicine \& Child Neurology, 59(11), 1174-1180. https://doi.org/10.1111/dmcn.13552

Lie, K. K., Grøholt, E. K., \& Eskild, A. (2010). Association of cerebral palsy with Apgar score in low and normal birthweight infants: Population based cohort study. BMJ, 341(7777), 817. 10.1136/bmj.c4990

Marcondes, C. B., \& Ximenes, M. de F. F. de M. (2015). Zika virus in Brazil and the danger of infestation by Aedes (Stegomyia) mosquitoes. Revista Da Sociedade Brasileira de Medicina Tropical, 49(1), 4-10. 10.1590/0037-8682-0220-2015

Mcintyre, S., Taitz, D., Keogh, J., Goldsmith, S., Badawi, N., \& Blair, E. (2013). A systematic review of risk factors for cerebral palsy in children born at term in developed countries. Developmental Medicine \& Child Neurology, 55(6), 499-508. 10.1111/dmcn.12017

Moster, D., Wilcox, A. J., Vollset, S. E., Markestad, T., \& Lie, R. T. (2010). Cerebral palsy among term and postterm births. JAMA, 304(9), 976-982. 10.1001/jama.2010.1271

Nelson, K. B., \& Blair, E. (2015). Prenatal Factors in Singletons with Cerebral Palsy Born at or near Term. The New England Journal of Medicine, 373(10), 946-953. 10.1056/NEJMra1505261

Oliveira, M. R., Nascimento, L. E. C., Moraes, B. L. J., Souza, W. S., Pita, W. S., Melo, G. L. R., \& Mazzoccante, R. P. (2021). Efeitos de práticas corporais no desenvolvimento motor em crianças e adolescentes com paralisia cerebral. Research, Society and Development, 10(2), e31710212627. 10.33448/rsd-v10i2.12627

Oskoui, M., Coutinho, F., Dykeman, J., Jetté, N., \& Pringsheim, T. (2013). An update on the prevalence of cerebral palsy: A systematic review and metaanalysis. Developmental Medicine and Child Neurology, 55(6), 509-519. 10.1111/dmcn.12080

Oztürk, A., Demirci, F., Yavuz, T., Yildiz, S., Değirmenci, Y., Döşoğlu, M., \& Avşar, Y. (2007). Antenatal and delivery risk factors and prevalence of cerebral palsy in Duzce (Turkey). Brain \& Development, 29(1), 39-42. 10.1016/j.braindev.2006.05.011

O’Callaghan, M. E., MacLennan, A. H., Gibson, C. S., McMichael, G. L., Haan, E. a., Broadbent, J. L., \& Dekker, G. A. (2011). Epidemiologic Associations With Cerebral Palsy. Obstetrics \& Gynecology, 118(3), 576-582. 10.1097/AOG.0b013e31822ad2dc

Pakula, A. T., Van Naarden Braun, K., \& Yeargin-Allsopp, M. (2009). Cerebral Palsy: Classification and Epidemiology. Physical Medicine and Rehabilitation Clinics of North America, 20(3), 425-452. 10.1016/j.pmr.2009.06.001

Persson, M., Razaz, N., Tedroff, K., Joseph, K. S., \& Cnattingius, S. (2018). Five- and 10-minute Apgar scores and risks of cerebral palsy and epilepsy: population based cohort study in Sweden. BMJ, 360, k207. 10.1136/bmj.k207

Petridou, E., Koussouri, M., Toupadaki, N., Papavassiliou, A., Youroukos, S., Katsarou, E., \& Trichopoulos, D. (1996). Risk factors for cerebral palsy: A casecontrol study in Greece. Scandinavian Journal of Public Health, 24(1), 14-26. http://www.scopus.com/inward/record.url?eid=2-s2.026444532411\&partnerID=40\&md5=39ffb899cf06df2b75403c5492f4bab6

Rosenbaum, P., Paneth, N., Leviton, A., Goldstein, M., Bax, M., Damiano, D., \& Jacobsson, B. (2007). A report: The definition and classification of cerebral palsy April 2006. Developmental Medicine and Child Neurology, 49(S.109), 8-14. 10.1111/j.1469-8749.2007.tb12610.x

Saadi, H. R., Sutan, R., Dhaher, A. M., \& Alshaham, S. A. (2012). Maternal and foetal risk factors of cerebral palsy among Iraqi children. A case control study. Open Journal of Preventive Medicine, 2(3), 350-358. 10.4236/ojpm.2012.23051

Sellier, E., Platt, M. J. M. J., Andersen, G. L. G. L., Krägeloh-Mann, I., De La Cruz, J., Cans, C., \& Mejaski-Bosnjak, V. (2016). Decreasing prevalence in cerebral palsy: A multi-site European population-based study, 1980 to 2003. Developmental Medicine and Child Neurology, 58(1), 85-92. 10.1111/dmcn.12865

Serdaroğlu, A., Cansu, A., Özkan, S., \& Tezcan, S. (2006). Prevalence of cerebral palsy in Turkish children between the ages of 2 and 16 years. Developmental Medicine and Child Neurology, 48(6), 413-416. 10.1017/S0012162206000910

Silva, A. K. R., Barata, M. F. O., Rabelo, A. R. M., Silva, L. P., \& Marcelino, J. F. Q. (2020). Ações da Terapia Ocupacional durante visitas escolares a crianças e adolescentes com deficiência motora. Research, Society and Development, 9(8), e971986715. 10.33448/rsd-v9i8.6715

Stelmach, T., Pisarev, H., \& Talvik, T. (2005). Ante- and Perinatal Factors for Cerebral Palsy: Case-Control Study in Estonia. Journal of Child Neurology, 20(8), 654-661. 10.1177/08830738050200080401

Victora, C. G., Aquino, E. M., Carmo Leal, M., Monteiro, C. A., Barros, F. C., \& Szwarcwald, C. L. (2011). Maternal and child health in Brazil: Progress and challenges. The Lancet, 377(9780), 1863-1876. 10.1016/S0140-6736(11)60138-4

Walstab, J., Bell, R., Reddihough, D., Brennecke, S., Bessell, C., \& Beischer, N. (2002). Antenatal and intrapartum antecedents of cerebral palsy: a case-control study. The Australian \& New Zealand Journal of Obstetrics \& Gynaecology, 42(2), 138-146. 10.1111/j.0004-8666.2002.00138.x 
Research, Society and Development, v. 10, n. 5, e35710515075, 2021

(CC BY 4.0) | ISSN 2525-3409 | DOI: http://dx.doi.org/10.33448/rsd-v10i5.15075

World Health Organization. (2016). International Statistical Classification of Diseases and Related Health Problems (10th ed.). Genebra: World Health Organization. Retrieved from: http://apps. who.int/classifications/icd10/browse/2016/en

Yeargin-Allsopp, M., Van Braun, K. N., Doernberg, N. S., Benedict, R. E., Kirby, R. S., \& Durkin, M. S. (2008). Prevalence of cerebral palsy in 8-year-old children in three areas of the united states in 2002: A multisite collaboration. Pediatrics, 121(3), 547-554. 10.1542/peds.2007-1270 